\title{
TERAPI KELOMPOK BERBASIS SEKOLAH DAN KELUARGA PADA REMAJA YANG MENGALAMI GANGGUAN DEPRESI
}

\section{SCHOOL AND FAMILY BASED ON GROUP THERAPY FOR ADOLESCENCE WITH DEPRESSION}

\author{
Hamidah \\ Marlina S Mahajudin \\ Fakultas Psikologi Universitas Airlangga Surabaya \\ E-mail: hamidah_dra@yahoo.com
}

\begin{abstract}
This study was aimed to decrease depression among adolescence by School and Family Based Group Therapy for Adolescence with Depression. The participants of this study was 30 adolescences grade 2 of public and private high school in city $X$, which were divided into boy and girl experiment group, and control group. This study included 25 parents and teachers. This study showed that there was a decreased rate of depression among boy and girl experiment group, also higher understanding about the problem of mental health among parents and teachers, which included symptoms, identifications, helping behavior, reversing and intervention of depression. Based on this, schools and families were expected to give social support for adolescences.
\end{abstract}

Keywords: depression, social support, group counseling.

\begin{abstract}
ABSTRAK
Penelitian ini bertujuan untuk mengurangi depresi di kalangan remaja dengan terapi kelompok berbasis sekolah dan keluarga. Para peserta penelitian ini adalah 30 remaja kelas 2 dari SMA negeri dan swasta di kota $X$, dibagi menjadi kelompok eksperimen dan kelompok kontrol. Penelitian ini meliputi 25 orang tua dan guru. Penelitian menunjukkan bahwa ada penurunan tingkat depresi di kalangan anak laki-laki dan kelompok perempuan eksperimen, pemahaman juga lebih tinggi tentang masalah kesehatan mental di kalangan orang tua dan guru, yang gejala, identifikasi, perilaku membantu, membalikkan dan intervensi. Berdasarkan pada sekolah ini, dan keluarga diharapkan dapat memberikan dukungan sosial bagi remaja.
\end{abstract}


Kata kunci: depresi, dukungan sosial, konseling kelompok.

Berdasarkan hasil penelitian Hamidah (2007) diketahui bahwa remaja yang mengalami gangguan depresi di kota $X$ cukup besar. Sampel penelitian sebanyak 1.054 orang yang terdiri dari 484 subjek perempuan dan 570 subjek laki-laki. Hasil penelitian memperlihatkan bahwa sampel dengan depresi sedang sebanyak $4.022 \%$ dan depresi berat sebesar $87,8 \%$. Sisanya, sebanyak 9,09\%, mengalami depresi pada tingkat akut. Jumlah subjek perempuan yang mengalami depresi pada tingkat akut sebanyak 11,98\%, lebih banyak dibanding subjek laki-laki sebanyak $6,4 \%$.

Penyebab depresi yang diketahui antara lain beban dan tuntutan pendidikan, hubungan dengan teman dekat dan orang tua, kehilangan orang terdekat, dan masalah finansial. Temuan lain dari penelitian ini adalah subjek penelitian dengan jenis kelamin perempuan lebih banyak yang mengalami depresi pada tingkat berat bila dibandingkan dengan subjek laki-laki. Sementara analisis kualitatif data penelitian menunjukkan bahwa subjek perempuan lebih banyak memerlukan dukungan sosial dan emosional dari lingkungannya dari pada laki-laki. Sedikit sekali subjek yang memerlukan bantuan atau dukungan kognitif.

Untuk mengatasi depresi yang dirasakan, tindakan yang dilakukan pada awalnya adalah mengurung diri atau menyendiri baik di dalam ruangan maupun di luar ruangan, serta bercerita kepada teman atau orang tua. Orang yang dipilih untuk membantunya adalah orang tua, teman, dan saudara.

Meyer (2002) mengemukakan definisi depresi sebagai gangguan mood dan afek, yang disertai simtom utama berupa suasana hati yang jelek dan kehilangan hedonia. Simtom utama ini sering disertai oleh simtom sekunder, yaitu menarik diri dari situasi sosial atau kontak dengan orang lain, merasa tidak ada harapan dan tidak berguna, ingin bunuh diri atau mati, gangguan tidur, lambat dalam psikomotorik, menurunnya selera makan, merasa bersalah, kurang konsentrasi, perilaku merokok dan alkohol meningkat, serta menangis tanpa alasan.

Sementara itu Greist (1987) mendefinisikan depresi merupakan kecemasan yang berkesinambungan serta ditandai oleh adanya gejala yang dapat didiagnosis, seperti adanya perubahan suasana hati, motivasi, pola pikir, dan perubahan fungsi fisik dan motorik. Beck (1985) menjelaskan depresi adalah keadaan abnormal pada seseorang yang ditunjukkan oleh adanya tanda-tanda dan gejala-gejala, seperti suasana hati yang murung, sikap pesimistik, kehilangan spontanitas, dan tanda-tanda vegetatif yang spesifik.

Selanjutnya, Wenar dan Kerig (2000) berdasarkan DSM IV mengatakan bahwa 
depresi adalah gangguan penyesuaian dengan suasana hati yang depresif yang dialami oleh seseorang. Kondisi ini ditandai oleh adanya emosi yang tidak menyenangkan dalam waktu yang singkat atau ditandai dengan adanya masalah perilaku, seperti sedih, ingin menangis, keputusasaan, merasa tidak berdaya, merasa tidak berguna dalam merespon situasi yang penuh dengan stres.

Berdasarkan pendapat-pendapat di atas dapat disimpulkan bahwa gangguan depresi adalah gangguan yang menimbulkan perubahan atau penurunan pada bidang kognitif, afektif dan motorik. Gangguan ini akan menimbulkan banyak kerugian bagi penderitanya. Apabila gangguan ini tidak mendapatkan intervensi yang tepat, terdapat kemungkinan akan berkembang menjadi gangguan psikosis yang lebih berat, yaitu skizofrenia.

Depresi tidak terjadi secara tiba-tiba, namun merupakan suatu proses yang dialami individu dalam kehidupannya. Gangguan yang terjadi karena adanya berbagai keadaan yang kurang menyenangkan sebelumnya menyebabkan seseorang merasa tertekan. Perasaan kurang menyenangkan yang bertumpuk dan tidak terselesaikan dapat menyebabkan individu merasa stres dan apabila tidak ditangani secara tepat dapat mengakibatkan depresi. Adapun beberapa penyebab timbulnya depresi, menurut Mash dan Wolfe (1999), adalah sebagai berikut: a) Mengalami situasi penuh dengan tekanan yang sulit diselesaikan, b) Kehilangan kontak dengan orang terdekat, c) Berpikir tentang hal-hal negatif pada dirinya, d) Tidak ada seorang pun yang dapat dipercaya, e) Tidak mempunyai kawan, f) Berada di sekitar orang dengan gangguan depresi, g) Memiliki kecenderungan dalam keturunan, h) Adanya perubahan kimiawi pada otaknya.

Sementara itu, menurut Noelen dan Hoeksama (2004), penyebab seseorang mengalami gangguan depresi adalah faktor internal individu dan faktor eksternal individu yang secara teoritis dapat ditinjau dari beberapa perspektif. Pertama, perspektif attachment, yang mengatakan bahwa adanya hubungan yang signifikan antara terjadinya attachment yang tidak aman dan kondisi depresif seseorang. Kedua, perspektif kognitif yang mengatakan bahwa adanya hubungan yang sangat signifikan antara skema negatif dari kognitif seseorang dan kondisi perasaan depresif.

Dalam konteks interpersonal (pengaruh keluarga), depresi disebabkan oleh adanya: 1) kondisi stres yang akut atau kronis, 2) kurangnya dukungan sosial dalam relasional, 3) keluarga yang malang atau sengsara, 4) adanya konflik antar orang tua, 5) meningkatnya depresi pada orang tua, dan 6) kehilangan orang tua atau pengasuh. Sementara dari konteks interpersonal (hubungan teman sebaya) diketahui bahwa anak-anak yang mengalami kekurangan keterampilan 
sosial akan mengalami depresi, misalnya kekurangan dukungan sosial dari teman sebaya, kurangnya kompetensi sosial, merasa kesepian, dan kurang memiliki keterampilan dalam problem solving. Sedangkan konteks organik mengatakan bahwa orang tua yang depresif akan menurunkan anak-anak yang memiliki kecenderungan depresif juga (Noelen \& Hoeksama, 2004).

Berdasarkan penjelasan di atas dapat disimpulkan bahwa beberapa faktor yang diduga sebagai penyebab gangguan depresi, yaitu 1) Adanya pemikiran otomatis yang negatif pada diri sendiri, orang lain dan lingkungannya, 2) Adanya aspek behavioral yang dipelajari, yaitu adanya reaksi negatif atas kejadian yang tidak menyenangkan, dan 3) Adanya hubungan interpersonal yang kurang baik dengan orang lain dan lingkungannya.

Banyak model pendekatan terapi yang dapat digunakan untuk membantu menangani gangguan. Namun penanganan efektif tergantung pada etiologi dan dimensi depresi yang dialami oleh individu. Walau bagaimanapun penanganan depresi memerlukan pendekatan yang integratif dan komprehensif, sehingga dapat membantu penanganan secara mendasar dan menyeluruh agar diperoleh hasil yang maksimal.

Terapi yang diberikan bagi penderita depresi dapat dilakukan secara individual maupun kelompok. Sampai saat ini belum ada studi pendahuluan yang khusus ditujukan untuk memahami remaja dengan gangguan depresi serta bagaimana intervensi yang tepat, mudah, dan murah. Sebab studi selama ini banyak dilakukan secara individual dengan pendekatan terapi medika mentosa (obat). Padahal biaya untuk intervensi semacam ini sangatlah mahal. Selain itu belum ada program pemerintah maupun swasta yang memikirkan tentang solusi yang dapat dilakukan untuk mencegah dan menyembuhkan gangguan depresi yang dapat dilakukan oleh keluarga atau lingkungan. Padahal pada 2006 pemerintah Malaysia telah mencanangkan program SK2 (satu keluarga satu konselor), yaitu program pencegahan gangguan kesehatan mental dimulai dari keluarga.

Hamamci (2006) juga meneliti tentang perbandingan efektivitas dari tritmen psikodrama terintegrasi dengan tritmen CBT dan cognitive behavioral group therapy untuk gangguan depresi. Hasil penyelidikan menunjukkan bahwa baik psikodrama dengan cognitive behavior therapy dan cognitive behavior therapy kelompok dapat menurunkan tingkat depresi, pemikiran negatif, dan sikap disfungsi yang dialami oleh subjek penyelidikan.

Selanjutnya, Franklin (2002) berpendapat bahwa psikoterapi yang berpengaruh untuk depresi adalah 1) Konseling suportif untuk membantu mengurangi hopelessness, 2) Terapi kognitif dimaksudkan untuk mengubah pikiran pesimis, tidak realistik dan 
kritik terhadap dirinya sendiri, 3) Terapi problem solving berguna untuk area kehidupan pribadi yang merupakan sumber stres dan mendukung munculnya depresi, 4) Terapi behavior bermanfaat untuk mengembangkan keterampilan koping yang lebih baik, keterampilan interpersonal untuk membantu problem solving dan relationship. Hasil dari penelitian tersebut menemukan bahwa konseling suportif dapat mengurangi depresi. Individu yang depresi memerlukan kemampuan problem solving skills, stress management, comunication sklills, life manajement skills, dan relationship skills.

Sementara itu Siqueland, Rinn, dan Diamond (2005) melakukan penelitian tentang perbedaan efektivitas intervensi CBT (cognitive behavior therapy) dengan kombinasi antara CBT - AFBT (Attachment family base treatment) untuk menurunkan kecemasan, fobia sosial, dan depresi. Hasil penelitian menyatakan terdapat penurunan depresi dan kecemasan secara signifikan pada subjek, baik setelah pemberian perlakuan maupun setelah tindak lanjut yang dilakukan 3 bulan setelah perlakuan. Dari dua macam perlakuan tidak ditemukan adanya perbedaan efektivitas yang signifikan antara metode CBT dan kombinasi CBTAFBT.

Berdasarkan beberapa penelitian di atas dapat diketahui bahwa tidak ada satu model terapi yang efektif untuk menyembuhkan gangguan depresi, namun terdapat pengaruh yang positif dari terapi
CB dan AFBT untuk menyembuhkan gangguan depresi. Terapi iniakan berfungsi secara maksimal apabila dilakukan secara integratif dan komprehensif dengan terapi lain. Tujuannya adalah untuk mengubah pemikiran, perilaku maupun memberikan dukungan sosial untuk mengubah persepsi individu yang mengalami depresi.

Kerangka pemikiran teoritis yang dibangun dalam penelitian ini adalah teori depresi Beck (1985) yang mengatakan bahwa gangguan depresi diakibatkan oleh adanya pemikiran yang negatif. Sedangkan untuk melihat etiologinya, pemikiran negatif ini disebabkan oleh adanya perilaku negatif yang dari lingkungan serta adanya pengalaman relasional yang negatif pula. Berdasarkan pemikiran tersebut dapat disimpulkan bahwa faktorfaktor yang membuat pemikiran seseorang menjadi negatif adalah adanya perlakuan lingkungan dan hubungan relasional yang kurang menyenangkan. Konsep pemikiran negatif juga dipengaruhi oleh adanya ketidakmampuan seseorang menemukan makna hidupnya serta kurang mampu membangun harga diri secara positif. Oleh sebab itu individu cenderung melihat dirinya secara negatif yang disebabkan faktor perlakuan dari lingkungan yang dapat menimbulkan pemikiran negatif terhadap lingkungan. Untuk mengubah pemikiran tersebut, menurut Beck, pikiranlah yang harus diubah supaya menjadi positif, rasional, dan optimis. Selain itu agar hubungan interpersonalnya dengan lingkungan 
menjadi lebih baik, ia perlu mendapatkan dukungan sosial mulai dari pola asuh dan dukungan dari kelompok sebaya. Untuk itu diperlukan adanya kombinasi terapi antara cognitive behavior dengan pola asuh dan dukungan sosial yang berbasis keluarga. Kombinasi terapi ini diharapkan mampu mengurangi pemikiran negatif serta meningkatkan kebermaknaan hidup dan harga diri seseorang, sehingga simtom

depresi yang dirasakannya dapat ber-kurang.

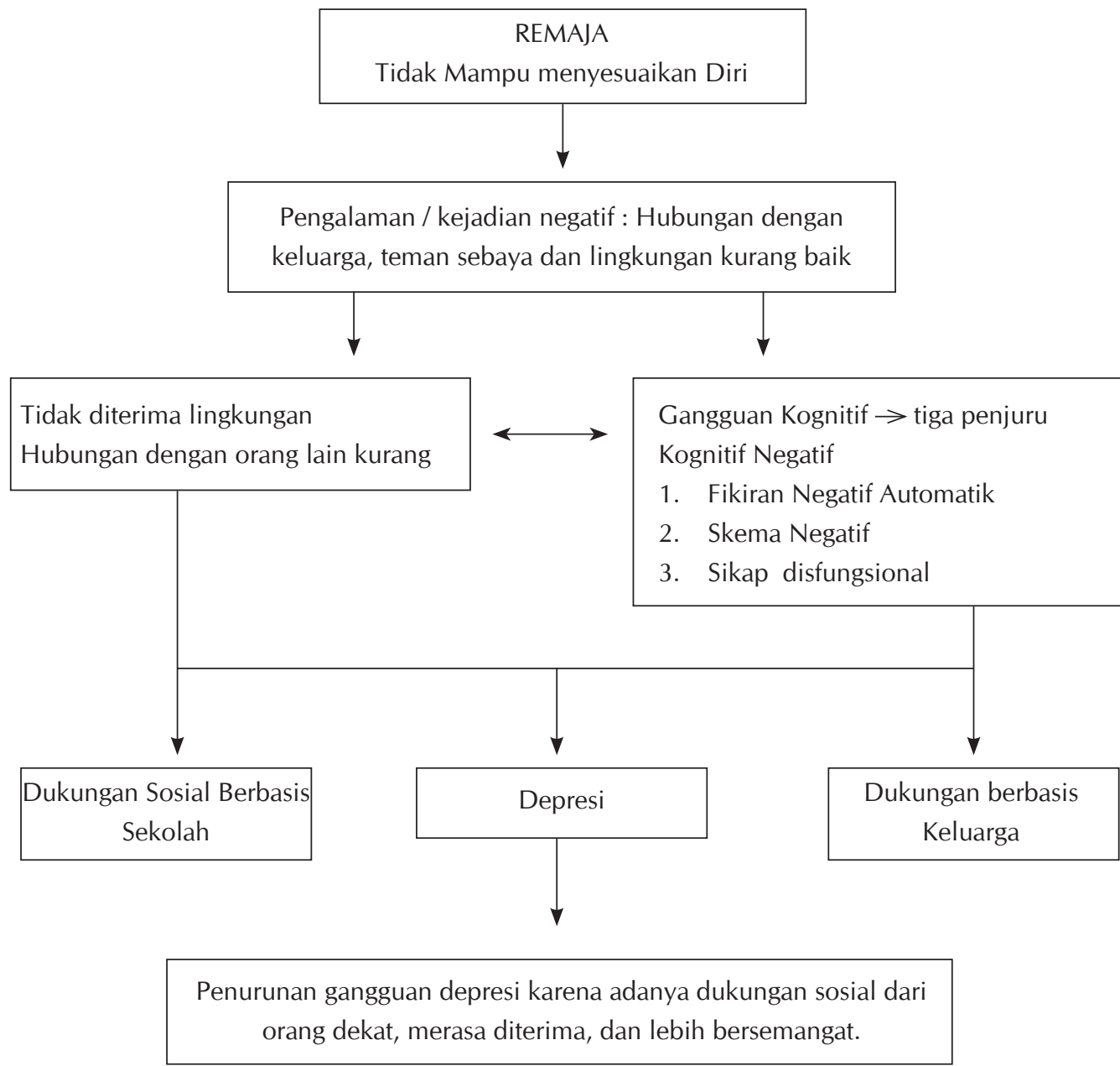


Gambar 1. Kerangka konseptual

Depresi, menurut Klerman (1984), merupakan kegagalan dan ketidakmampuan seseorang dalam membangun relasi sosial dengan orang dekat secara tepat dan positif. Oleh sebab itu, ia memerlukan respon, penerimaan, pengakuan, dan semangat secara positif dari lingkungan dalam bentuk dukungan sosial. Dukungan sosial ini dapat diperoleh dari orang lain yang berinteraksi dengan individu. Sebab berdasarkan penelitian Hamidah (2007), dukungan sosial yang diperlukan adalah dari teman, sahabat, saudara dan orang tua. Adapun bentuk dukungan sosial yang diperlukan adalah semangat, motivasi, kedekatan, dorongan, dan teman untuk berbagi.

Manusia sebagai makhluk sosial membutuhkan kehadiran manusia lain untuk berinteraksi. Kehadiran orang lain di dalam kehidupan pribadi seseorang begitu diperlukan. Hal ini terjadi karena seseorang tidak mungkin memenuhi kebutuhan fisik maupun psikologisnya sendirian. Individu membutuhkan dukungan sosial baik yang berasal dari atasan, teman sekerja maupun keluarga (Ganster, dkk., 1986).

Dukungan sosial diartikan sebagai kesenangan, bantuan, yang diterima seseorang melalui hubungan formal dan informal dengan yang lain atau kelompok (House Smet, 1999) membedakan empat macam dukungan sosial, yaitu (i) Dukungan emosional. Individu membutuhkan empati dari orang lain; (ii) Dukungan penghargaan. Individu membutuhkan penghargaan yang positif, penilaian atas usaha-usaha yang dilakukan, dan peran sosial yang terdiri atas umpan balik; (iii) Dukungan informatif. Individu membutuhkan nasehat, pengarahan, saran-saran untuk mengatasi masalah pribadi maupun masalah pekerjaan; (iv) Dukungan instrumental. Individu membutuhkan bantuan berupa benda, peralatan atau sarana guna menunjang kelancaran kerja.

Sebagaimana definisi di atas dapatlah diambil suatu simpulan bahwa dukungan sosial merupakan ketersediaan sumber daya yang memberikan kenyamanan fisik dan psikologis yang didapat dari pengetahuan bahwa individu tersebut dicintai, diperhatikan, dihargai dan diperlukan oleh orang lain dan ia juga merupakan anggota dalam satu kelompok yang berdasarkan kepentingan bersama. Dukungan sosial sangat diperlukan bagi seseorang untuk meningkatkan kesehatan, kesejahteraan, kebahagiaan bahkan mungkin sedikit menjadi lebih panjang umur karena merasa tidak tertekan, tidak diabaikan, tidak dihindari dan masih diperhitungkan kehadirannya.

Menurut Ganster, dkk (1986), sumber-sumber dukungan sosial dapat berasal dari keluarga, rekan sekerja, dan atasan. Seorang perawat di rumah sakit diharapkan mendapat dukungan sosial, baik dari atas, teman sekerja, maupun 
keluarga. Jika mendapat dukungan sosial, maka perawat dapat menjalankan tugasnya dengan lebih baik dan dengan demikian kinerjanya meningkat. Akan tetapi, jika tidak memperoleh dukungan sosial, maka perawat akan mengalami kebingungan, merasa tidak mempunyai sandaran untuk mengadukan permasalahannya. Keadaan yang demikian tentu akan berdampak negatif pada para perawat dan akan tercermin pada kinerja yang tidak memuaskan.

Berdasarkan definisi di atas dapatlah dilihat bahwa sumber dari dukungan sosial yang diperoleh seseorang untuk membantu memberikan kekuatan fisik maupun non fisik adalah berasal dari orang lain yang memiliki hubungan dekat. Sebagaimana dikatakan oleh Lubis (2003) bahwa sumber dukungan sosial adalah orang lain yang akan berinteraksi dengan individu sehingga individu tersebut dapat merasakan kenyamanan secara fisik dan psikologis. Orang lain ini terdiri atas pasangan hidup, orang tua, saudara, anak, teman, rekan kerja, staf medis, atau anggota dalam kelompok masyarakat.

Sheridan dan Radmacher (1992), Safarino (1998), serta Taylor (1999) membagi bentuk dukungan sosial ke dalam lima bentuk, yaitu a) dukungan instrumental (tangible assistance). Bentuk dukungan ini merupakan penyediaan materi yang dapat memberikan pertolongan langsung seperti pinjaman uang, pemberian barang, makanan serta pelayanan. Bentuk dukungan ini mengurangi stres karena individu dapat langsung memecahkan masalahnya yang berhubungan dengan materi. Dukungan instrumental sangat diperlukan terutama dalam mengatasi masalah yang dianggap dapat dikontrol; b) dukungan informasional. Bentuk dukungan ini melibatkan pemberian informasi, saran atau umpan balik tentang situasi dan kondisi individu. Jenis informasi seperti ini dapat menolong individu untuk mengenali dan mengatasi masalah dengan lebih mudah; c) dukungan Emosional. Bentuk dukungan ini membuat individu memiliki perasaan nyaman, yakni dipedulikan dan dicintai oleh sumber dukungan sosial, sehingga individu dapat menghadapi masalah dengan lebih baik. Dukungan ini sangat penting dalam menghadapi keadaan yang dianggap tidak dapat dikontrol; d) dukungan pada harga diri. Bentuk dukungan ini berupa penghargaan positif pada individu, pemberian semangat, persetujuan pada pendapat individu, perbandingan yang positif dengan inidividu lain. Bentuk dukungan ini membantu individu dalam membangun harga diri dan kompetensi; e) dukungan dari kelompok sosial. Bentuk dukungan ini akan membuat individu akan merasa menjadi anggota dari suatu kelompok yang memiliki kesamaan minat dan aktivitas sosial dengannya. Dengan begitu individu akan merasa memiliki teman senasib.

Bentuk intervensi bagi gangguan depresi, menurut Klerman (1984), adalah dengan memberikan dukungan sosial. 
Untuk memperoleh penanganan dan intervensi depresi yang efektif, baik dalam bentuk mengubah cara berpikir, semangat, tempat curhat, nasehat, memotivasi dan mendengarkan cerita maupun pemberian dukuangan. Sesuai dengan hasil pemetaan tersebut, maka penelitian ini akan mengkaji efektivitas intervensi dukungan sosial yang berbasis keluarga dan sekolah untuk menurunkan gangguan depresi pada remaja. Dalam penelitian ini, yang akan dikaji adalah seberapa jauh pemahaman orang tua dan guru serta teman terhadap gangguan depresi dan seberapa jauh efektivitas terapi kelompok dengan dukungan sosial yang berbasis keluarga dan sekolah mampu menurunkan gangguan depresi.

Teori depresi mazhab ketiga, yaitu teori interpersonal, menjelaskan bahwa gangguan depresi disebabkan oleh adanya kedekatan secara sosial, emosional dan psikologis. Teori ini berdasar dan memperhatikan kedekatan hubungan seseorang dengan orang lain dan peranannya dalam hubungan tersebut (Noelen \& Hoeksema, 2004). Gangguan dalam fungsi hubungan interpersonal yang mengarah kepada kehilangan yang mendalam, adanya konflik, transisi peran, kekurangan hubungan interpersonal, adanya orang tua tunggal, keterasingan sosial, adanya interaksi antara mood dan peristiwa interpersonal yang kurang menyenangkan merupakan sumber terjadinya gangguan depresi (Mash \& Wolfe, 1999). Kebingungan dan hambatan yang dialami seseorang dalam memainkan peranannya dalam membangun hubungan dengan orang lain merupakan sumber dan penyebab gangguan depresi.

Sebagaimana digambarkan dalam teori attachment, teori interpersonal ini menganggap bahwa anak-anak yang tidak atau kurang mengalami pendidikan dan pengasuhan secara konsisten, kurang mendapatkan respon, kurang hangat, merasa tidak aman akan merupakan masalah dalam relasinya dengan orang lain. Permasalahan dalam relasi ini kewujudannya akan terlihat secara mental sebagai model hubungan yang negatif antara seseorang dengan orang lain. Model ini memainkan peranan yang mengharapkan dukungan yang sesuai dari orang lain. Apabila dalam kehidupannya ia kurang memperoleh dukungan sosial yang diharapkan, maka ia akan mengakibatkan kurangnya atau rendahnya harga diri atau self worth. Apabila hal ini terjadi secara berterusan, maka akan mengakibatkan adanya gangguan depresi.

Sebagaimana dikatakan oleh Noelen dan Hoeksema (2004), gangguan keyakinan yang dialami oleh seseorang merupakan hasil dari kelekatan yang tidak aman pada masa kanak-kanak. Teori interpersonal dari depresi mendukung beberapa hasil penyelidikan tentang kecemasan, kelekatan (attechment) yang tidak aman. Keyakinan negatif yang 
disfungsional akan menyebabkan harga diri yang rendah dan perwujudannya dalam bentuk simtom depresi yang lebih kuat.

Berdasarkan penjelasan dalam latar belakang di atas., hipotesis penelitian ini adalah terapi kelompok yang berbasis keluarga dan sekolah efektif untuk menangani gangguan depresi pada remaja yang mengalami depresi.

\section{METODE PENELITIAN}

Penelitian ini merupakan penelitian kuantitatif, yang terdiri dari dua bagian, yaitu penelitian deskriptif kuantitatif dan penelitian kuasi eksperimen. Variabel bebas penelitian ini adalah terapi kelompok dalam bentuk dukungan sosial dan variabel terikatnya adalah depresi pada remaja.

\section{Subjek Penelitian}

Subjek dalam penelitian ini adalah remaja SMA yang mengalami gangguan depresi sebanyak 40 orang lelaki dan perempuan. Subjek dibagi menjadi dua kelompok, yaitu kelompok eksperimen dan kontrol. Masing-masing kelompok terdiri atas 20 orang subjek. Kelompok eksperimen diberi perlakuan dalam bentuk terapi kelompok dukungan sosial dari keluarga dan sekolah. Anggota keluarga dan teman serta guru BP di sekolah diberikan pelatihan untuk memberikan dukungan sosial dalam bentuk terapi kelompok kepada remaja yang mengalami depresi.

\section{Rancangan Penelitian}

Penelitian ini adalah penelitian kuasi eksperimen. Rancangan penelitian yang dipakai dalam penelitian ini adalah rancangan kelompok kontrol pratespascates (pretest-post test control group design). Data depresi dikumpulkan dalam bentuk prates dan pascates untuk melihat ada tidaknya perbedaan pada kelompok eksperimen dan kontrol sebelum dan sesudah eksperimen.

\section{Pengumpulan Data}

Data penelitian deskriptif dikumpulkan melalui kuesioner dukungan sosial, sedangkan data depresi dikumpulkan melalui skala depresi dari Beck (Beck Depression Inventory atau BDI skala II). Data deskriptif dikumpulkan pada saat prates, sedangkan data depresi dikumplkan prates dan pascates.

\section{Metode Analisis Data}

Data pada penelitian ini ditampilkan secara deskriptif dalam bentuk grafik untuk menggambarkan pengetahuan dan pemahaman subjek terhadap depresi dan dukungan sosial yang diberikan oleh lingkungan keluarga dan sekolah. Sedangkan data depresi dari remaja digunakan untuk dianalisis dengan teknik uji beda (t-test). Uji beda dipakai dengan tujuan untuk mengetahui perbedaan depresi pada prates dan pascates antara kelompok eksperimen dan kontrol. Pelaksanaan teknik analisis data dilakukan dengan 
menggunakan program SPSS versi 13.

\section{HASIL PENELITIAN}

\section{Hasil Penelitian Deskriptif}

Pemahaman orang tua, guru, dan teman tentang gangguan depresi dan perbedaan pemahaman setelah memperoleh pelatihan dapat dilihat sebagaimana hasil pemetaan pada gambar 2 .

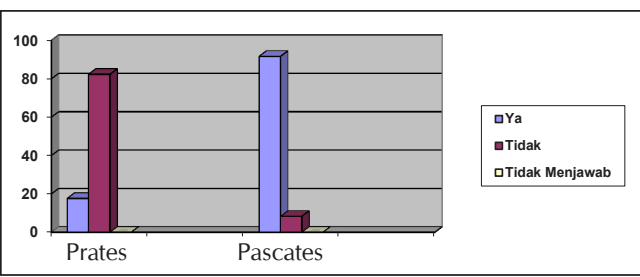

Gambar 2. Diagram skor pemahaman tentang gangguan depresi?

Berdasarkan grafik batang tersebut di atas dapat diketahui bahwa masyarakat yang terdiri dari orang tua, guru, dan teman memiliki pemahaman yang kurang terhadap depresi sebelum mendapatkan pelatihan dan pemahamannya meningkat setelah mendapatkan pelatihan. Jumlah peserta yang mengetahui gangguan depresi meningkat dari 18\% menjadi $80 \%$ lebih, sedangkan yang menjawab tidak tahu menurun dari $80 \%$ menjadi $90 \%$ lebih.

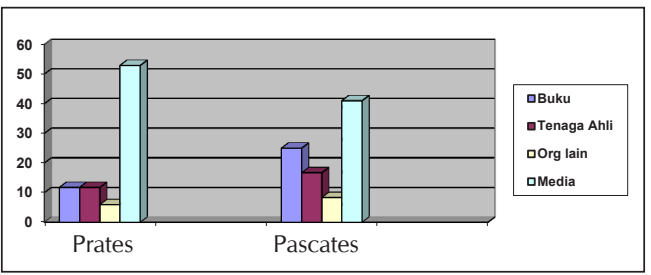

Gambar 3. Diagram skor sumber informasi mengetahui gangguan depresi

Grafik di atas menunjukkan sumber informasi bagi orang tua, guru, dan teman sebaya tentang gangguan depresi bersumber dari buku dan tenaga ahli masing-masing mengalami peningkatan dari $10 \%$ menjadi $25 \%$ dan $15 \%$, sedangkan yang berasal dari media menurun dari $50 \%$ menjadi $40 \%$.

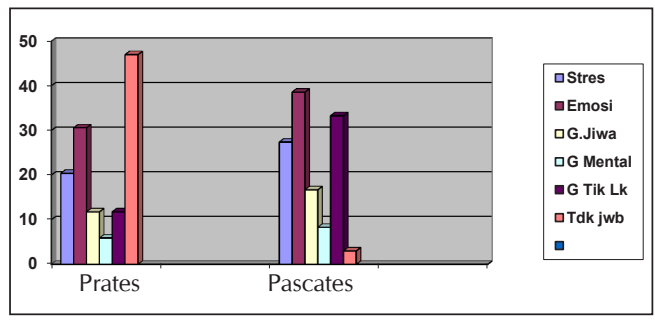

Gambar 4. Diagram skor bentuk tentang gangguan depresi?

Grafik di atas menunjukkan pemahaman gangguan emosi juga berbeda dari prates ke pascates. Terdapat peningkatan pada pemahaman gangguan depresi sebagai stres, gangguan emosi, gangguan jiwa, dan gangguan mental serta gangguan tingkah laku terdapat peningkatan pemahaman dari peserta. Sementara terjadi penurunan jumlah peserta yang tidak menjawab karena tidak tahu dari $45 \%$ lebih menjadi kurang dari 5\%.

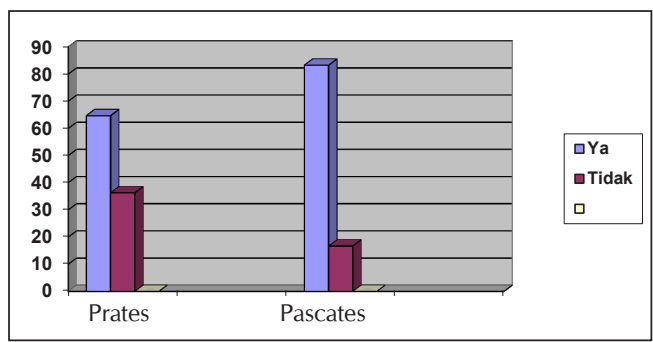


Gambar 5. Diagram skor tentang penyebab gangguan depresi

Grafik di atas menunjukkan jumlah peserta yang tidak mengetahui dan yang mengetahui penyebab gangguan depresi. Terdapat peningkatan jumlah peserta yang mengetahui gangguan depresi dari $60 \%$ menjadi $80 \%$ dan penurunan peserta yang tidak mengetahui gangguan depresi dari $35 \%$ menjadi $15 \%$.

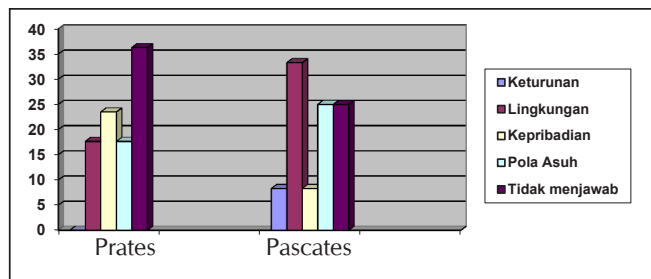

Gambar 6. Diagram skor tentang penyebab gangguan depresi

Grafik di atas menunjukkan pemahaman terhadap faktor penyebab gangguan depresi pada peserta, yang awalnya terdapat $35 \%$ peserta tidak mengetahui menurun menjadi $25 \%$. Sementara terdapat perubahan pada pemahaman peserta penyebab depresi dari faktor keturunan, lingkungan, kepribadian, dan pola asuh.

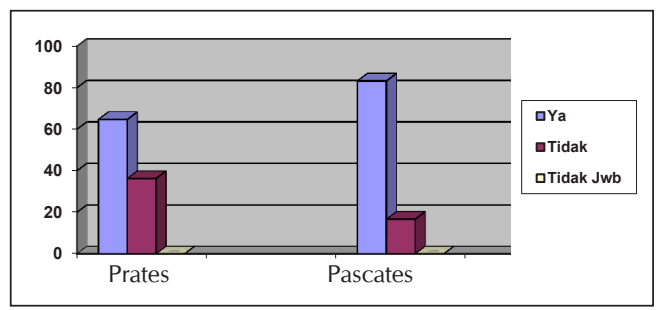

Gambar 7. Diagram skor tentang gejala-gejala gangguan depresi
Grafik di atas menunjukkan bahwa terdapat perubahan pemahaman peserta terhadap gejala gangguan depresi dari prates $60 \%$ menjadi $80 \%$ setelah pascates, dan terjadi penurunan ketidakpahaman gejala gangguan depresi dari 35\% menjadi $15 \%$ saat pascates.

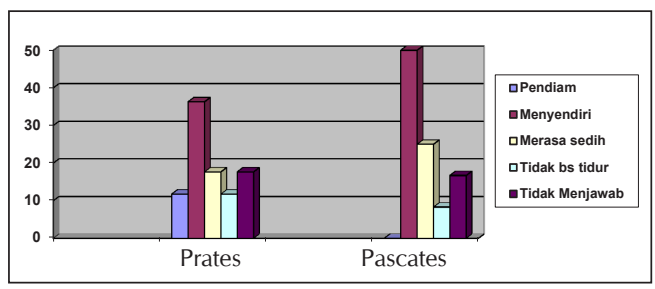

Gambar 8. Diagram skor tentang gejala gangguan depresi

Grafik di atas memperlihatkan pemahaman peserta tentang gejala gangguan depresi. Peserta yang tidak mengetahui pada prates sebanyak $17 \%$ menurun menjadi $15 \%$ setelah pascates.

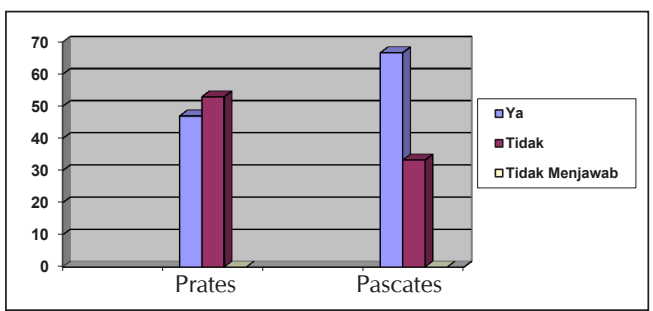

Gambar 9. Diagram skor pemahaman apabila anggota keluarga mengalami gangguan depresi

Grafik di atas menunjukkan adanya perubahan pemahaman tentang kemampuan mengenal dan identifikasi gejala gangguan depresi pada aggota keluarga. Peserta awalnya mengetahui gejala tersebut sebesar $45 \%$ menjadi $65 \%$ setelah mendapatkan pelatihan. Sementara yang tidak mengetahui dari 
$55 \%$ menurun menjadi $35 \%$ setelah menerima pelatihan.

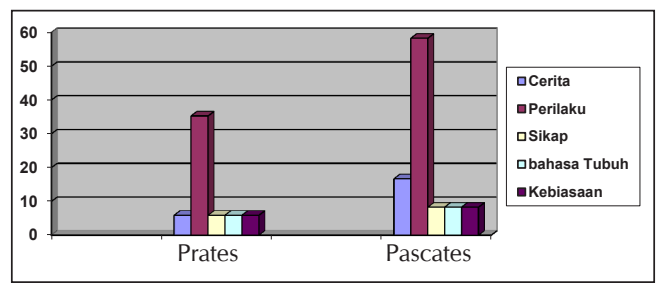

Gambar 10. Diagram skor cara mengetahui gejala gangguan tersebut pada anggota keluarga anda

Grafik tersebut menunjukkan pemahaman peserta terhadap gejala gangguan depresi pada orang lain melalui berbagai tanda. Terdapat peningkatan pemahaman tentang gangguan depresi yang dipahami dari cerita dan perilaku dari $5 \%$ dan 35\% menjadi $15 \%$ dan 55\%. Begitu juga dari sikap, bahasa tubuh, dan kebiasaan, namun peningkatannya tidak signifikan.

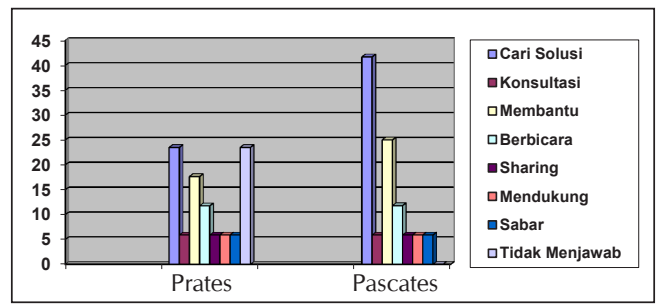

Gambar 11. Diagram skor tentang usaha untuk membantu mereka?

Grafik tentang usaha yang dilakukan oleh orang tua, guru dan teman terhadap individu yang mengalami gangguan depresi juga terjadi peningkatan. Usaha-usaha yang dimaksud meliputi membantu mencari solusi, konsultasi, membantu secara langsung, berbicara, berbagi, mendukung dan menasehati.
Namun terdapat penurunan yang cukup signifikan pada peserta yang awalnya tidak mengetahui dari $25 \%$ menjadi $2 \%$.

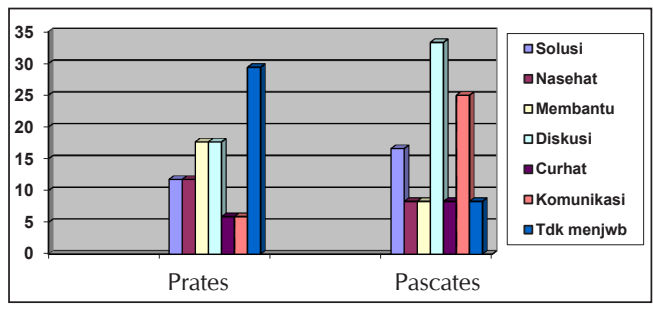

Gambar 12. Diagram skor cara untuk membantu anggota keluarga yang mengalami gangguan depresi

Grafik di atas menunjukkan perubahan jumlah peserta yang tidak mengetahui bagaimana cara membantu individu yang mengalami gangguan depresi dari $30 \%$ menjadi $8 \%$. Sementara terjadi peningkatan pemahaman cara membantu individu yang mengalami gangguan depresi baik dengan cara mencarikan solusi, maupun berkomunikasi, curhat dan diskusi dengan individu.

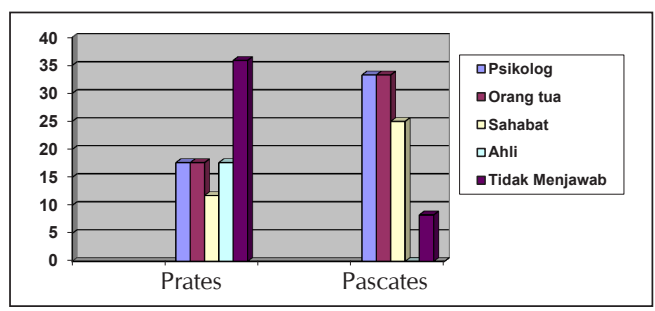

Gambar 13. Diagram skor tentang orang yang anggap tepat untuk dimintai bantuan lebih lanjut

Grafik di atas menunjukkan pemahaman peserta terhadap siapa yang dapat digunakan sebagai tempat rujukan ketika peserta mengetahui ada individu 
yang mengalami gangguan depresi. keinginan perubahan yang dilakukan oleh Peningkatan tersebut terdapat pada peserta setelah mendapatkan pelatihan. profesi psikolog, orangtua dan sahabat. Perubahan yang sangat signifikan terjadi Sementara terdapat menurunan jumlah keinginan perubahan perilaku terhadap peserta yang memberikan rujukan pada tenaga ahli dan tidak mengetahui siapa yang dirujuk, dari $16 \%$ dan $35 \%$ menjadi $2 \%$ dan $7 \%$.

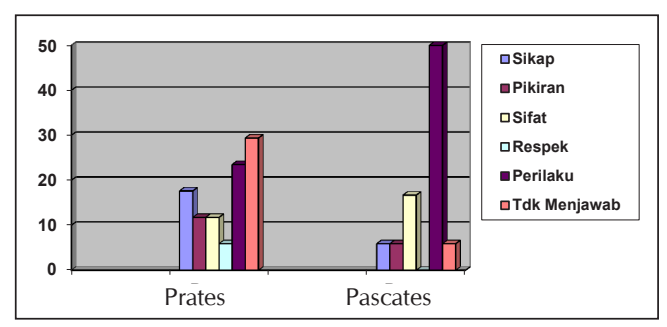

Gambar 14. Diagram perubahan setelah mengikuti pelatihan ini

Grafik tersebut menunjukkan adanya individu yang mengalami gangguan depresi dari $25 \%$ menjadi $50 \%$, serta perubahan sifat dari $10 \%$ menjadi $18 \%$, dan dari peserta yang tidak mengetahui dari $28 \%$ menjadi $5 \%$. Sementara untuk aspek sikap dan pikiran terdapat penurunan yang tidak signifikan.

\section{Hasil Penelitian Inferensial}

Efektivitas intervensi dukungan sosial yang berbasis keluarga dan sekolah. Tujuan penelitian ketiga dan keempat adalah mengetahui perbedaan atau penurunan skor depresi pada remaja sebelum dan setelah mendapatkan

intervensi dukungan sosial. Datanya dapat dilihat pada tabel.

Tabel 1. Skor Depresi Subjek Laki-laki, Perempuan dan kontrol

\begin{tabular}{cccccccccc}
\hline \multirow{2}{*}{$\begin{array}{c}\text { No } \\
\text { Subjek }\end{array}$} & \multicolumn{3}{c}{$\begin{array}{c}\text { Skor Dep Subj } \\
\text { Perempuan }\end{array}$} & \multicolumn{3}{c}{$\begin{array}{c}\text { Skor Dep Subj } \\
\text { Laki-laki }\end{array}$} & \multicolumn{3}{c}{$\begin{array}{c}\text { Skor Dep Subj kel } \\
\text { kontrol }\end{array}$} \\
\cline { 2 - 10 } & Pra & Pasca & Gain & Pra & Pasca & Gain & Pra & Pasca & Gain \\
\hline 1 & 53 & 53 & 0 & 54 & 52 & 2 & 62 & 61 & 1 \\
2 & 57 & 50 & 7 & 59 & 53 & 6 & 58 & 59 & -1 \\
3 & 53 & 53 & 0 & 56 & 53 & 3 & 56 & 55 & 1 \\
4 & 55 & 50 & 5 & 51 & 40 & 7 & 54 & 54 & 0 \\
5 & 50 & 46 & 4 & 53 & 50 & 3 & 53 & 54 & -1 \\
6 & 53 & 50 & 3 & 55 & 49 & 6 & 52 & 53 & 1 \\
7 & 58 & 50 & 8 & 53 & 48 & 5 & 56 & 52 & 4 \\
8 & 52 & 56 & 4 & 53 & 49 & 4 & 53 & 53 & 0 \\
9 & 54 & 49 & 5 & 56 & 52 & 4 & 55 & 54 & 1 \\
10 & 58 & 50 & 8 & 54 & 47 & 7 & 60 & 60 & 0 \\
\hline
\end{tabular}

Keterangan: Skor Dep Subj = Skor Departemen subjek

$$
\begin{array}{ll}
\text { Pra } & =\text { skor Prates } \\
\text { Pasca } & =\text { skor Pascates }
\end{array}
$$


Gain $=$ Gain score

Tabel 2. Paired Samples Test : Gain Score Perempuan - kontrol

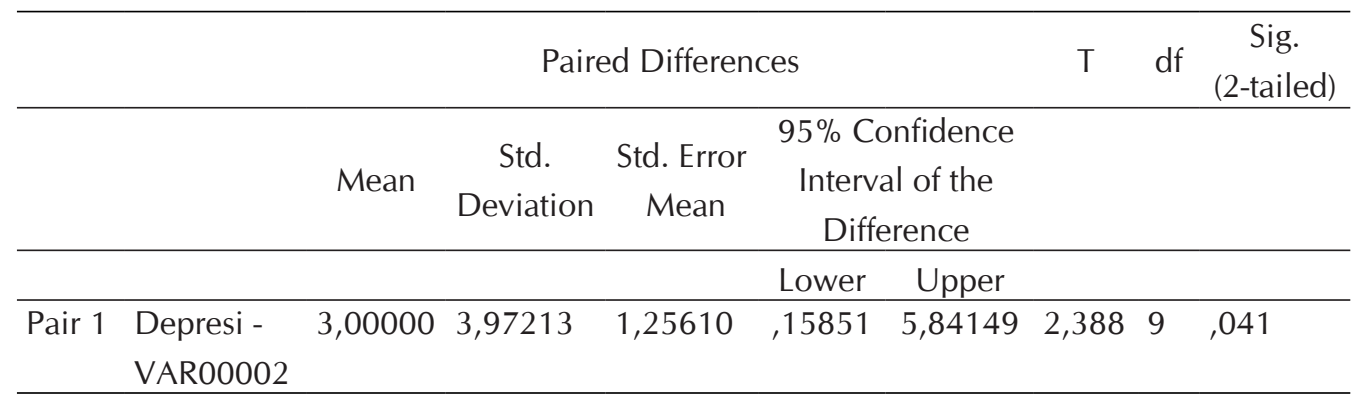

Berdasarkan data di atas dilakukan uji beda dengan menggunakan teknik t-test

untuk melihat perbedaan gain score Artinya terdapat perbedaan signifikan depresi pada kelompok eksperimen antara gain score pada kelompok perempuan dan kelompok kontrol. Hasil eksperimen perempuan dan kelompok analisis tersebut menunjukkan nilai $\mathrm{t}$ kontrol. sebesar 0,041 . Nilai t tersebut lebih kecil dari 0,05 dengan taraf signifikansi $95 \%$.

Tabel 3. Paired Samples Test : Gain 
Score Laki-laki - kontrol

\begin{tabular}{|c|c|c|c|c|c|c|c|c|c|}
\hline & & \multicolumn{5}{|c|}{ Paired Differences } & $\mathrm{T}$ & $\mathrm{df}$ & Sig. \\
\hline & & Mean & $\begin{array}{c}\text { Std. } \\
\text { Deviation }\end{array}$ & $\begin{array}{c}\text { Std. Error } \\
\text { Mean }\end{array}$ & \multicolumn{2}{|c|}{$\begin{array}{c}\text { 95\% Confidence } \\
\text { Interval of the } \\
\text { Difference }\end{array}$} & & & \\
\hline & & & & & Lower & Upper & & & \\
\hline \multirow[t]{2}{*}{ Pair 1} & VAR0000 & $-4,10000$ & 2,37814 & ,75203 & $-5,80122$ & $-2,39878$ & $-5,452$ & 9 & ,000 \\
\hline & VAR00003 & & & & & & & & \\
\hline
\end{tabular}

Berdasarkan data di atas dilakukan uji t dengan menggunakan teknik t test untuk melihat perbedaan gain score depresi pada kelompok eksperimen laki-laki dan kelompok kontrol. Hasil analisis tersebut menunjukkan nilai t sebesar 0,000 . Nilai t tersebut lebih kecil dari 0,005 dengan taraf signifikansi $95 \%$. Artinya terdapat perbedaan signifikan antara gain score pada kelompok eksperimen laki-laki dan kelompok kontrol.
Tabel 4. Paired Samples Test : Gain Score Perempuan - Laki-laki

\begin{tabular}{|c|c|c|c|c|c|c|c|c|}
\hline & \multicolumn{5}{|c|}{ Paired Differences } & \multirow[t]{2}{*}{$\mathrm{T}$} & \multirow[t]{3}{*}{$d f$} & \multirow{3}{*}{$\begin{array}{c}\text { Sig. } \\
\text { (2-tailed) }\end{array}$} \\
\hline & \multirow[t]{2}{*}{ Mean } & \multirow[t]{2}{*}{$\begin{array}{c}\text { Std. } \\
\text { Deviation }\end{array}$} & \multirow[t]{2}{*}{$\begin{array}{l}\text { Std. Error } \\
\text { Mean }\end{array}$} & \multicolumn{2}{|c|}{$\begin{array}{c}\text { 95\% Confidence } \\
\text { Interval of the } \\
\text { Difference }\end{array}$} & & & \\
\hline & & & & Lower & Upper & & & \\
\hline $\begin{array}{ll}\text { Pair } 1 & \text { Depresi - } \\
& \text { VAR00003 }\end{array}$ & $-1,10000$ & 3,17805 & 1,00499 & $-3,37344$ & 1,17344 & $-1,095$ & 9 & ,302 \\
\hline
\end{tabular}

Berdasarkan data di atas dilakukan uji beda dengan menggunakan teknik t-test 
untuk melihat perbedaan gain skor depresi pada kelompok eksperimen perempuan dan laki-laki. Hasil analisis tersebut menunjukkan nilai t sebesar 0,302 . Nilai $t$ tersebut lebih besar dari 0,05 dengan taraf signifikansi $95 \%$. Artinya tidak terdapat perbedaan signifikan antara gain skor pada kelompok eksperimen perempuan dan kelompok laki-laki.

Efektivitas perbedaan skor depresi sebelum dan setelah intervensi pada lakilaki dan perempuan. Tujuan penelitian

kelima adalah mengetahui perbedaan atau penurunan skor depresi pada remaja lakilaki dan perempuan sebelum dan setelah mendapatkan intervensi dukungan sosial. Hasil analisis data dapat dilihat pada tabel-tabel di bawah ini.

Tabel 5. Paired Samples Test perbedaan skor depresi prates dan pascates pada perempuan

\begin{tabular}{l} 
Mean $\begin{array}{c}\text { Std. } \\
\text { Deviation }\end{array}$ Mean \\
\hline \\
\hline Pair 1 VAR00005 - 3,63636 3,72217 1,12228 \\
VAR00006 \\
Berdasarkan data di atas dilakukan \\
uji beda dengan menggunakan teknik \\
t-test untuk melihat perbedaan skor rata- \\
rata depresi prates dan pascates pada \\
kelompok eksperimen perempuan. Hasil \\
analisis tersebut menunjukkan nilai $\mathrm{t}$ \\
sebesar 0,091. Nilai t tersebut lebih \\
besar dari 0,005 dengan taraf signifikansi \\
95\%. Artinya tidak terdapat perbedaan \\
signifikan antara skor rata-rata prates dan \\
pascates pada kelompok eksperimen
\end{tabular}

perempuan.

Tabel 6. Paired Samples Test peribedailedi)

$95 \%$. Confidence

skor depresi prates dan pascates pada
Interval of the

Difference laki-laki

\begin{tabular}{ccc}
\hline & Lower & Upper \\
28 & 1,13578 & 6,13695 \\
\hline
\end{tabular}

$3,240 \quad 10 \quad$ P,jibgd Differences

\begin{tabular}{llllr}
\hline & & & & \\
& Mean & $\begin{array}{c}\text { Std. } \\
\text { Deviation }\end{array}$ & Std. Error \\
& Mean \\
& & & & Lo \\
\hline Pair 1 VAR00008 - 5,10000 & 2,60128 &, 82260 & 3,2 \\
& VAR00009 & & & \\
\hline
\end{tabular}

Berdasarkan data di atas dilakukan uji beda dengan menggunakan teknik t-test untuk melihat perbedaan skor ratarata depresi prates dan pascates pada kelompok eksperimen laki-laki. Hasil analisis tersebut menunjukkan nilai $t$ 
sebesar 0,000. Nilai t tersebut lebih kecil dari 0,005 dengan taraf signifikansi 95\%. Artinya terdapat perbedaan signifikan antara skor rata-rata prates dan pascates pada kelompok eksperimen laki-laki.

\section{PEMBAHASAN}

Hasil penelitian ini membuktikan bahwa pelatihan tentang pemberian pemahaman terhadap gangguan depresi dan intervensi dukungan sosial yang diberikan kepada orang tua, guru, dan sahabat atau teman mempunyai efek yang cukup positif dalam meningkatkan pengetahuan, pemahaman, kemampuan identifikasi, keinginan membantu, mengetahui bentuk bantuan, serta ahli sebagai rujukan serta penanganan lebih jauh terhadap remaja yang mengalami gangguan depresi.

Hasil penelitian ini dapat dipahami bahwa depresi memang banyak dialami oleh masyarakat, namun masih belum banyak orang yang mengetahui apa sebenarnya gangguan depresi, gejalagejala yang dialami, serta faktor penyebab gangguan tersebut apa lagi penanganan dan tempat profesional sebagai ahli yang dapat menangani masalah depresi. Oleh sebab itu, pelatihan ini merupakan bentuk sosialisasi yang cukup dapat dirasakan manfaatnya oleh masyarakat. Sementara ini masyarakat masih agak kesulitan membedakan antara stres, depresi, dan skzofrenia. Hal ini selaras dengan program Departemen Kesehatan
RI bahwa tahun 2010 adalah tahun Indonesia sehat, maka Departemen Kesehatan juga menggalakkan program penyuluhan, pendidikan, dan sosialisasi kepada masyarakat tentang kesehatan baik fisik maupun mental. Kegiatan ini juga dikuatkan oleh hasil penelitian Surjaningrum (2007) yang menunjukkan hasil bahwa masyarakat secara umum masih belum banyak yang memiliki pemahaman yang luas atau mendalam tentang kesehatan mental dan gangguan kesehatan mental serta hal-hal yang terkait dengan kesehatan mental.

Penelitian lain menunjukkan bahwa dukungan sosial sangat diperlukan oleh berbagai kelompok orang untuk membantu meningkatkan kesehatan, baik kesehatan fisik ataupun kesehatan psikologis. Lubis (2003) menemukan hasil penelitian tentang peranan dukungan sosial terhadap pasien gagal ginjal. Hasil penelitian ini menunjukkan bahwa pasien gagal ginjal yang menjalani hemodialisa memerlukan dukungan sosial yang berbeda dengan dukungan sosial yang remaja terima. Dukungan sosial yang berlebihan justru menimbulkan stres bagi pasien, sehingga remaja memerlukan dukungan sosial yang tepat baik dalam bentuk, intensiats atau frekuensi serta sumber dukungan sosial itu sendiri. Selain itu pasien laki-laki memerlukan dukungan sosial yang berbeda dengan perempuan, baik dalam bentuk, intensiats dan frekuensinya. 
Penelitian tentang peran dukungan sosial terhadap kecemasan wanita pada kehamilan pertama telah dilakukan oleh Ramli (2003) bahwa dukungan sosial mampu mengurangi kecemasan pada kehamilan pertama. Menurut Walta Gautama (Kompas, 8 Desember 2007), dukungan sosial sangat diperlukan bagi penderita kanker. Melalui dukungan sosial dari orang dekat, penderita kanker akan merasakan adanya kedekatan, kenyamanan, dan ada perasaan diperhatikan, sehingga diharapkan dapat mendorong tumbuhnya semangat untuk sembuh dan panjang umur. Semangat ini merupakan ubat penyembuh paling mujarab.

Hasil uji beda tersebut di atas juga didukung dengan uji beda yang lain, yaitu uji beda antara skor depresi prates dan pascates baik pada kelompok lakilaki maupun kelompok perempuan. Hasil uji beda menunjukkan adanya perbedaan yangsignifikan pada skordepresi prates dan pascates pada kelompok laki-laki, namun tidak ada perbedaan yang signifikan pada kelompok perempuan. Artinya intervensi dukungan sosial mempunyai pengaruh yang cukup signifikan untuk menurunkan skor depresi pada kelompok laki-laki dan tidak untuk kelompok perempuan. Dengan demikian, hasil dari penelitian ini cukup konsisten. Proses depresi bagi perempuan memerlukan penanganan dengan proses yang cukup konsisten, intensif dan banyak menggunakan katarsis atau ekspresi feeling. Sementara laki-laki lebih banyak memerlukan proses yang mampu mengubah pikiran negatif menjadi positif, yang tidak rasional menjadi lebih rasional dan lebih logis. Hasil ini juga didukung oleh beberapa hasil penelitian lain sebelumnya.

Penelitian Lestari (2008) juga menemukan peranan dukungan sosial bagi penderita skizofrenia. Peneliti menggunakan pendekatan kualitatif, maka didapat hasil bahwa kedua keluarga tersebut memberikan dukungan sosialnya terhadap penderita, walaupun setiap keluarga memiliki bentuk tersendiri. Dukungan sosial tersebut meliputi dukungan emosional, dukungan penghargaan, dukungan instrumental, dukungan informasi serta dukungan jaringan sosial. Peran dukungan sosial yang keluarga berikan tersebut pada umumnya berpengaruh baik pada penderita dan dapat mencegah penderita mengalami kekambuhan.

Sementara itu, Sari (2007) melakukan penelitian untuk mengetahui peran dukungan sosial keluarga dan beban kerja terhadap stres mahasiswa, dan dari analisis data menunjukkan bahwa: 1) Ada pengaruh sangat signifikan beban kerja, dukungan sosial keluarga, jenis kelamin, umur, dan status perkawinan terhadap stres mahasiswa sebesar 46.978 persen, $p=0.000 ; 2$ ) Ada pengaruh sangat signifikan beban kerja terhadap stres mahasiswa sebesar 16.800 persen, $\mathrm{p}=$ $0,000 ; 3)$ Tidak ada pengaruh dukungan sosial keluarga terhadap stres mahasiswa; 
4) Tidak ada pengaruh jenis kelamin terhadap stres mahasiswa; 5) Tidak ada pengaruh umur terhadap stres mahasiswa;

6) Ada pengaruh status perkawinan terhadap stres mahasiswa sebesar 27.394 persen, $\mathrm{p}=0.000$.

Hasil penelitian di atas juga didukung oleh penelitian tentang dukungan sosial dan gangguan depresi dan kecemasan pada karyawan telah dilakukan oleh Plaisier, de Bruijn, deGraaf, tenHave, Beekman, dan Pennin (2007). Hasil penelitian menunjukkan bahwa kondisi kerja yang sangat kurang menyenangkan merupakan sumber penting dari stres dan memberikan sumbangan terhadap pengembangan gangguan depresif dan kecemasan. Tindakan dukungan sosial sebagai suatu penahan dan pelindung dari berkembangnya gangguan depresif dan kecemasan yang timbul sebagai akibat dari kondisi kerja yang sangat kurang menyenangkan.

Kemampuan prediktif dari dukungan sosial terhadap gangguan depresi telah dilakukan oleh Herwig, Wirtz, dan Jurgen Bengel (2003). Hasil penelitiannya menjelaskan bahwa nilai prediktif antara dukungan sosial, pengasuhan, dan partnership terhadap depresif dan masalah perilaku pada anak. Simpulan penelitian ini menunjukkan masalah perilaku anak dapat diprediksikan oleh pengasuhan dan partnership dari ibunya. lbu dengan pengasuhan yang sulit dan kurang memberikan partnership lebih memberikan sumbangan terhadap masalah perilaku anak. Depresif dan dukungan sosial memberikan nilai prediktif secara tidak langsung terhadap masalah anak. Keterbatasan penelitian ini adalah data penelitian dikumpulkan berdasarkan sampel cross sectional. Sedangkan data dikumpulkan dari cerita ibu. Hasil penelitian memberikan rekomendasi perlunya program untuk memberikan intervensi pada pengasuhan yang kurang memberikan partnership dari orang tua.

Hasil penelitian ini menunjukkan tidak ada perbedaan rata-rata skor depresi pada kelompok laki-laki maupun perempuan setelah mendapatkan intervensi dukungan sosial. Artinya tidak ada perbedaan pengaruh dari intervensi dukungan sosial untuk menurunkan depresi baik pada kelompok laki-laki ataupun perempuan.

Tiga hasil penelitian sebelumnya menunjukkan bahwa intervensi terapi kelompok dengan strategi dukungan sosial lebih mampu menurunkan skor depresi secara signifikan pada kelompok laki-laki dari pada kelompok perempuan. Namun secara eksplisit perbedaan antara gain skor pada kelompok laki-laki dan kelompok perempuan tidak berbeda secara signifikan. Hal ini disebabkan adanya proses terapi yang dilakukan dalam penelitian ini tidak dapat berjalan secara maksimal sesuai dengan modul yang elah disusun oleh peneliti. Hal ini terjadi karena pada saat dilaksanakannya 
terapi di sekolah, beberapa kali peserta terapi terganggu oleh kegiatan sekolah yang harus diikuti oleh peserta meskipun tidak lama. Selain itu tidak selurunya peserta dapat mengikuti terapi secara terus menerus, beberapa peserta pernah tidak mengikuti terapi karena sakit atau tidak masuk sekolah. Untuk kelompok perempuan, ada peserta yang belum mampu terbuka secara penuh dalam mengungkapkan permasalahannya karena ada hubungannya dengan peserta lain yang terkait dengan teman dekat lain jenis. Kondisi ini dapat berpengaruh kepada proses katarsis menjadi kurang maksimal.

\section{PENUTUP}

\section{Simpulan}

Berdasarkan data dan hasil penelitian tentang remaja dengan gangguan depresi di atas dapatlah disimpulkan bahwa :

1. Terdapat perbedaan pemahaman peserta antara prates dan pascates (baik tentang pengenalan istilah, pengetahuan tentang gangguan depresi, penyebab, sumber pengetahuan, pengenalan dan identifikasi gangguan depresi, usaha yang dilakukan, siapa yang akan dijadikan tempat rujukan dan bentuk bantuan, serta keinginan mengubah baik pikiran, perilaku, sifat dan pola asuh) sehingga pelatihan yang diberikan kepada peserta mempunyai nilai manfaat untuk membantu peserta memahami masalah gangguan depresi.
2. Pelatihan tersebut cukup mampu mengubah pengetahuan, pemahaman, kemampuan mengidentifikasi, membantu, dan mengubah tingkah laku peserta terhadap individu yang mengalami gangguan depresi.

3. Tidak terdapat perbedaan skor depresi yang signifikan antara kelompok perempuan dan kelompok kontrol setelah diberikan intervensi dukungan sosial dari orang-orang dekat di sekitarnya.

4. Terdapat perbedaan skor depresi antara kelompok laki-laki dan kelompok kontrol setelah diberikan intervensi dukungan sosial dari orangorang dekat di sekitarnya.

5. Tidak terdapat perbedaan skor depresi antara kelompok perempuan dan kelompok kontrol setelah diberikan intervensi dukungan sosial dari orangorang dekat di sekitarnya.

6. Terdapat perbedaan rata-rata skor depresi pada kelompok laki-laki dan keleompok perempuan sebelum dan sesudah intervensi. Hal ini berarti intervensi mempunyai efek yang cukup signifikan untuk menurunkan gangguan depresi pada kelompok lakilaki dan perempuan.

7. Berdasarkan hasil analisis pada no 3 sampai dengan no 6 , dapat disimpulkan bahwa intervensi dukungan sosial dari orang-orang dekat (keluarga, teman, guru dan sahabat) mempunyai efek yang cukup signifikan untuk menurunkan skor depresi pada 
kelompok laki-laki dan perempuan, namun kesignifikannya tidak berbeda bila dibandingkan antara kelompok laki-laki berbanding perempuan.

\section{Saran}

1. Remaja perlu memberikan semangat, motivasi, dukunga, menerima, dan menghargai sahabat, teman, atau saudara yang sedang mengalami masalah. Selain itu ia juga perlu mengetahui tempat atau profesi apa atau siapa yang dapat menolong individu yang mengalami gangguan.

2. Bagi orang tua dan guru yang memiliki anak atau siswa remaja sudah saatnya belajar memahami dan lebih terbuka terhadap keinginan anak dan mendiskusikan serta membicarakan keinginan dan kemauan anak.

\section{DAFTAR PUSTAKA}

Beck,A.T. \& Rush, A.J. (1985). Cognitive Behavior Therapy of depression. New York: Guilford Press.

Bum, D.D. (2006). Depression for Adolescence. New York: McGraw Hill Inc.

Etzion, D. (1984). Moderating Effect of Social Support on The Stress-Burnout Relationship. Journal of Applied Psychology, 62, 615-621.

Franklin, G.T. (2002). Psychoterapy for Depression. USA: Harper Inc.

Ganster, D.C., Fusilier, M.R., \& Meyes,
B.T. (1986). Role of Social Social Support in The Experience of Stress at Work. Journal of Applied Psycholog, 71, 102-110.

Gilbert, H.B. (2000). Psycho Pathology. New York: McGraw Hill, Inc.

Greist, J.H., \& Jefferson, J.W. (1987). Depresi dan Penyembuhannya, Terjemahan. Jakarta: PT. Gunung Mulia.

Hamamci,Z. (2006). IntegrativePsychodrama and Cognitive Behavioral Therapy to Treat Moderate Depression. Journal of Art Therapy, 33, 199-207.

Hamidah. (2000). Perbedaan Kepekaan Sosial ditinjau Berdasarkan Persepsi terhadap Pola Asuh Orang Tua pada Remaja di Jawa Timur. Insan Media Psikologi, 4 (3), 131-160.

Hamidah, Ariana. A.T, \& Dewi. T,K. (2005). Depresi pada Remaja. Laporan Penelitian. Surabaya: Fakultas Psikologi Universitas Airlangga Surabaya.

Hamidah. (2007). Identifikasi Kebutuhan Psikologis dan Pengembangan Model Intervensi melalui Konseling Kelom-pok dengan Dukungan Sosial yang Berbasis Sekolah dan Keluarga Untuk Menurunkan Gangguan Depresi. Laporan Penelitian. Surabaya: LPPM Universitas Airlangga.

Herwig, J.E., Wirtz, M., \& Bengel, J. (2003). Depression, Partnership, Social Support, and Parenting: 
Interaction of Maternal Factors With Behavioral Problems of the Child. Journal of Affective Disorders, 80, 199-208.

Klerman, G.L.,Weissman, M.M, Rounsaville, B.J., \& Chevron, E.S. (1984). Interpersonal Therapy for depression. New York: Basic Book.

Kompas. (2 Nopember 2004). Angka Bunuh Diri pada Anak dan Remaja Semakin Meningkat. Jakarta.

Lestari. (2008). Peran Dukungan Sosial Kelaurga pada dalam Menjegah Relapse Pada Penderitan Schizophrenia. Skripsi. Tidak Diterbitkan. Surabaya: Fakultas Psikologi Unair.

Lubis. A.J. (2003). Peranan Dukungan Sosial Terhadap Pasien Penderita Gagal Ginjal. Thesis. Tidak Diterbitkan. Medan: Fakultas Kedokteran Universitas Sumatera Utara.

Mash, E.J. \& Wolfe, D.A. (1999). Abnormal Child Psychology. Wadsworth publishing Company. A Division of International Thomson Publishing Inc. US.

Meyer. G.L. (2002). Abnormal Psychology. New York: Mc.Graw Hill Inc.

National Institute of Mental Health. (2000). CBT for Depression. USA: National Institute of Mental Health
Noelen, S \& Hoeksema. (2004). Abnormal Psychology. $3^{\text {rd }}$ Ed. Boston: Higher Education McGraw Hill. University Of Michigan.

Parasuraman, S., Greenhause, J.H., \& Granrose, C.S. (1992). Role Stressor, Social Support, and Well-being Among Two-Career Couples. Journal of Organizational Behaviour, 13, 399-356.

Plaisier, I., de Bruijn, J.G.M., deGraaf. R., tenHave, M., Beekman, A.T.F., \& Penninxm, B.W.J.H. (2007). The contribution of working conditions and social support to the onset of depressive and anxiety disorders among male and female employees. Journal of Social Science \& Medicine, 64, 401-410.

Ramli, H. (2003). Pengaruh Dukungan Social Terhadap Kecemasan Wanita Hamil Pertama. Skripsi. Tidak diterbitkan. Malang: Fakultas Psikologi Universitas Muhamadiyah Malang.

Sarafino, E.P. (1998). Health Psychology. Biopsychosocial Interaction. ( $\left.3^{\text {rd }} \mathrm{Ed}\right)$. New York. John Willey and Son Inc.

Sari. (2007). Peran Dukungan Sosial Keluarga Dan Beban Kerja Terhadap Stres Mahasiswa. Tesis. Tidak diterbitkan. Yogyakarta: Fakultas Psikologi Universitas Gadjah Mada. 
Sallinen, M, Kinnunen, U, \& Ronka, A. Smet, B. (1999). Psikologi Kesehatan. (2004). Adoloscents`Experiences of Parental Employment ant Parenting: Connections to Adoloscents `Wellbeing. Journal of Adoloscence, 27, 221-237.

Sheridan, C.L. \& Radmaker., S.A. 1992. Health Psychology. Challenging the Biomedical Model. New York: John Willey and Son.

Siqueland, L., Rinn, M, \& Diamond, G.S. (2005). Cognitive Behavioral and Attachment Base Family Therapy for Anxious Adolescents: Phase I dan Phase II Study. Journal of Anxiety Disorder, 19, 361-381.

Taylor, S.E. (1999). Health Psychology. $\left(4^{\text {th }}\right.$ Ed). Boston: McGrawHill.Inc.

Wenar, C. \& Keirg, P. (2000). Developmental Psychopathology From Infancy through Adoloscence. Toronto: McGraw-Hill.

Wenar, C. (2004). Children and Adoloscence Psychopathology. Toronto. Mc.Graw Hill. 